This item was submitted to Loughborough's Institutional Repository (https://dspace.lboro.ac.uk/) by the author and is made available under the following Creative Commons Licence conditions.

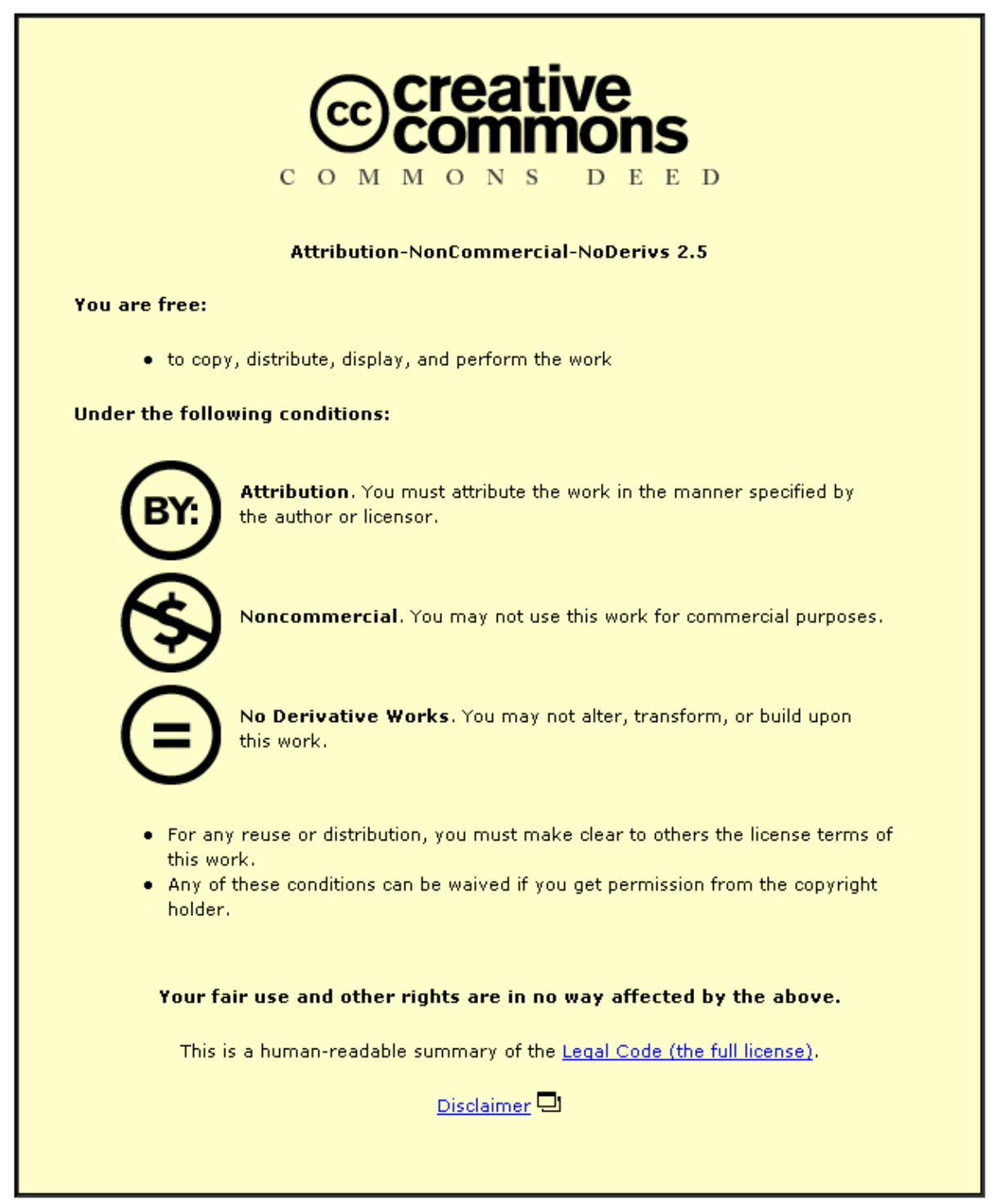

For the full text of this licence, please go to: http://creativecommons.org/licenses/by-nc-nd/2.5/ 


\section{Strategic marketing of water services in developing countries}

\section{Njiru and K. Sansom}

The recent (2000) global water supply and sanitation assessment by the World Health Organisation found that over one billion people do not have access to improved water supply. The finding points to the challenges faced by municipal engineers and other professionals responsible for the provision of water services in developing countries. Population growth and the increasing poverty, particularly in the urban areas, compound the challenge. A key objective for water utilities is to provide services to the growing population, including the poor, in a financially sustainable manner. Strategic marketing offers an innovative method of meeting this objective. Research aimed at adapting and developing a marketing approach for use in the water sector was carried out in a number of developing countries between 1999 and 2001 , with detailed field research in Kenya, Uganda and India. This paper discusses strategic marketing of urban water services and provides a methodology that water utilities could use to structure their service delivery options to customers while meeting their financial objectives. The paper outlines how utilities could structure service delivery with appropriate pricing and serve more excluded customers (including the poor) at affordable cost and achieve financial sustainability. The paper concludes that strategic marketing of water services has potential to improve services to existing and excluded (potential) customers while improving the utility's revenue base.

\section{INTRODUCTION}

As a consequence of urbanisation and rapid population growth in developing countries, urban water utilities face an enormous challenge in meeting the water requirements of urban dwellers. Indeed, the recent global water supply and sanitation assessment by the World Health Organisation found that over one billion people do not have access to improved water supply. ${ }^{1}$

Most water utilities in developing countries use the conventional technology-driven or product/supply-driven approach to water provision, which has clearly not been successful in meeting the water requirements of the rising urban population. High proportions of the urban population are completely excluded from conventional water services. Indeed, many water utilities and municipalities are not providing water services directly to a high proportion of the city population-50-70\% in many cities. ${ }^{2,3}$ People who do not receive water services from the utilities often rely on water vendors, to whom they pay high prices, or they use alternative water sources, often at high cost, that may be contaminated. The situation is becoming worse with high urban population growths of over $2-6 \%$ per year. The twin objectives of improving water services to all customers (including the urban poor) while achieving financial sustainability is a key challenge facing water utilities, especially in developing countries. ${ }^{4}$

Strategic marketing offers a systematic and flexible approach to providing improved and sustainable services to all groups of consumers, including the poor, in a financially sustainable manner. Research aimed at adapting and developing a marketing approach for use in the water sector was carried out in a number of developing countries, with detailed field research in Kenya, Uganda and India between 1999 and 2001. The findings from the Kenya research were used to prepare a detailed case study to demonstrate how the strategic marketing approach could improve management of urban water services, and thus improve services to the excluded population. This approach is derived from marketing concepts.

\section{STRATEGIC MARKETING CONCEPTS}

Marketing has been defined as 'the management process responsible for identifying, anticipating and satisfying customer requirements profitably. ${ }^{5}$ This definition implies that ongoing communication with existing and those excluded (potential) customers is required to check the effectiveness of efforts to identify, anticipate and satisfy customer requirements. While different water utilities have different financial objectives, all utilities need to generate sufficient funds to cover their costs, including a reasonable profit.

Another perspective on marketing is to view it as a set of tools. One such tool is the marketing mix or the seven Ps of marketing (product, price, promotion, place, people, process and presence) which are aspects to be reviewed in order to respond adequately to demand. ${ }^{6}$ A utility with a marketingorientated philosophy would have its entire operations, its personnel and its technical systems, being geared to providing improved customer satisfaction and to contribute towards meeting its financial objectives. Market segmentation, service differentiation and appropriate pricing are key to achieving these objectives. ${ }^{12}$ 


\section{RELEVANCE OF MARKETING IN THE WATER SECTOR}

Marketing is about satisfying customers while meeting the financial objectives of the organisation that is providing the services. In the context of a water utility, marketing is about satisfying customers in its area of operation while meeting the objectives of the water utility. A marketing approach can therefore be said to enable a water utility to meet two seemingly conflicting objectives

(a) social good (making water accessible to all customers, without excluding any segment of the population)

(b) economic good (providing water to customers profitably).

The objectives of water utilities are often reflected in their mission statements. For instance, the mission statement for the National Water Conservation and Pipeline Corporation (NWCPC) - the water utility with mandate to provide water services in Mombasa City, Kenya- states $^{7}$

'The Corporation is committed to providing a regular supply of high-quality water to its customers at an affordable price and at a reasonable profit to the corporation.'

Like many water utilities in developing countries, NWCPC Mombasa uses the conventional technology-driven or product/ supply-driven approach to water provision in the areas where it has mandate to operate. Recent research in Mombasa ${ }^{4}$ shows that NWCPC has not been able to meet its stated objectives. For instance, Table 1 shows that $96 \%$ of households living in informal settlements do not receive water directly from NWCPC, and are thus excluded from utility water services. Table 1 shows clearly that NWCPC has not been successful in meeting the water requirements of the rising urban population in Mombasa, and there is need to use a different approach to water provision. The alternative approach that a water utility can use in the provision of water services is the marketing approach, which puts emphasis on 'identifying, anticipating and satisfying customer requirements profitably'.

Apart from failing to meet the water requirements of a large proportion of existing (and potential) customers (Table 1), NWCPC is also not meeting its financial objectives. NWCPC's financial performance is weak $^{7}$ and this is largely due to its failure to adopt a marketing approach to water provision. Utilities that adopt a marketing-orientated philosophy can be said to be customer focused, with the intention of including all those interested in receiving the utility service. In the context of water services, no market segment should be excluded, water being an essential service.

A casual observation of the water situation in many cities of developing countries reveals that a thriving water market exists. Whereas the official water utility has the legal mandate to supply water to all customers in the city, other suppliers operate in the city as well. Evidence of the existence of a water market and the competition faced by utilities is seen in the form of ${ }^{4}$

(a) illegal connections to the water utility's distribution network

(b) private water vendors (handcarts and water tankers)

(c) individual and/or private water sources such as wells, boreholes and roof catchment

(d) other non-utility water sources.

One of the most significant findings of the customer survey carried out in Mombasa ${ }^{4}$ is that many customers have multiple water sources. This means that although utilities such as NWCPC have a legal mandate to supply water to all the people living in the city, in practice utilities often face substantial competition from other sources (mainly due to exclusion).

In Mombasa, the perceived monopoly status of NWCPC as a water undertaker in the city is not real-perhaps a reflection of

\begin{tabular}{|c|c|c|c|c|}
\hline Selected parameter & $\begin{array}{l}\text { Bungalows and } \\
\text { maisonettes: \% }\end{array}$ & Flats: \% & $\begin{array}{l}\text { I, } 2 \text { or } 3 \\
\text { roomed dwellings: \% }\end{array}$ & $\begin{array}{c}\text { Informal } \\
\text { settlements: \% }\end{array}$ \\
\hline $\begin{array}{l}\text { Do not receive water directly } \\
\text { from NWCPC }\end{array}$ & 35 & 17 & 58 & 96 \\
\hline $\begin{array}{l}\text { Receive continuous supply of } \\
\text { water from NWCPC }\end{array}$ & 30 & 31 & 13 & 2 \\
\hline $\begin{array}{l}\text { Receive water once or twice } \\
\text { per day from NWCPC }\end{array}$ & 27 & 40 & 24 & । \\
\hline $\begin{array}{l}\text { Households with individual } \\
\text { house connections }\end{array}$ & 94 & 78 & 23 & 2 \\
\hline $\begin{array}{l}\text { Households with shared } \\
\text { connections }\end{array}$ & 0 & 12 & 28 & 4 \\
\hline $\begin{array}{l}\text { Households without any piped } \\
\text { water connection }\end{array}$ & 6 & 10 & 49 & 94 \\
\hline $\begin{array}{l}\text { Obtain water from handcart } \\
\text { vendors }\end{array}$ & 18 & 45 & 57 & 46 \\
\hline Obtain water from kiosks & 0 & 22 & 56 & 79 \\
\hline Main water source & $\begin{array}{c}\text { Own house connections } \\
(59 \%) \text { and own } \\
\text { boreholes or wells (25\%) }\end{array}$ & $\begin{array}{l}\text { Own house connections } \\
(7 \mid \%) \text { and shared } \\
\text { connections (I2\%) }\end{array}$ & $\begin{array}{l}\text { Water kiosks } \\
(44 \%) \text { and shared } \\
\text { connections }(23 \%)\end{array}$ & $\begin{array}{c}\text { Water kiosks (70\%) } \\
\text { and boreholes or } \\
\text { wells (I8\%) }\end{array}$ \\
\hline
\end{tabular}

Table I. Summary of existing service levels for people living in respective market segments in Mombasa ${ }^{4}$ 
the level of service the utility provides to customers. It is therefore necessary for NWCPC to market its services with a view to capture more of the existing water market and benefit fully from its legal monopoly status. This could lead to an increase of water sales with the potential for increase in revenue and thus enable NWCPC to attain financial sustainability. Application of marketing techniques can therefore enable the utility to survive and thrive in the water market. A strategic marketing plan enables an organisation to chart a course that could improve its effectiveness. An effective water utility is one that achieves its mission. In the case of NWCPC, the mission is 'to provide a regular supply of high-quality water to its customers' and make 'a reasonable profit'. ${ }^{7}$ NWCPC needs a strategic marketing plan to enable it to achieve this mission. ${ }^{8}$

Another perspective is that the above non-utility unconventional (alternative) sources provide water often at inflated prices and/or of poor quality. Consequently, the social and economic situation of the consumers is made worse. For the utility, a sizeable percentage of its potential revenue base remains untapped. An important aspect of the people excluded from conventional utility water services, including those who live in low-income settlements, is that many are willing to pay substantial amounts for improved services, with high levels of willingness to pay. ${ }^{4,12}$ Good opportunities exist for the utility to capture more of the water market served by unconventional methods, through strategic marketing.

\section{HOW TO MARKET WATER SERVICES}

Marketing of different water supply options has particular scope in infrastructure-constrained cities, which also have a high proportion of the population excluded from conventional water services. In areas where the water utility is unable to provide a $24 \mathrm{~h}$ water service (as in many developing countries), there is scope to increase quality of service by providing substantive and some peripheral service attributes using appropriate technical and management options. This can result in an increase in service quality and reliability, and thus enhance customers' perception of the value of the water service. This has the potential to increase customers' willingness to pay for the services, thus maximising utility income and improving prospects of financial sustainability.

Progressive customer-orientated water utilities appreciate the crucial importance of the customer as the reason why the utility exists. The key to marketing of water services is to know the customer. It is important to build beneficial exchange relationships with existing and excluded (potential) customers. A useful approach to achieve this is to use the concept of "customer value chain'. ${ }^{9}$

The concept of the customer value chain is to know, target, sell and service. In the context of the water sector, the customer value chain involves developing customer knowledge through market segmentation, service differentiation, service promotion and service provision. Details of this concept are as follows. ${ }^{4,10}$

(a) Know and understand the different customer and potential customer groups, including their attitudes, practices, perceptions, preferences and their willingness to pay and sustain payment for improved service options. Since water is perceived both as a social and an economic good, effort is needed to understand people's perceptions. Methods available for getting to know the perceptions of water users include customer questionnaire surveys, focus group discussions, customer consultative committees and local observation.

(b) Target specific customer groups or market segments (e.g. commercial customers and domestic customers in high-, medium- and low-income areas), with appropriate service options at sustainable water charges that consumers are willing to pay for. The range of feasible service options will, in practice, be location-specific, and will depend on both technical and management considerations. Options could include house connections, yard taps and water kiosks, with or without storage tanks, at appropriate price levels. Other options that can be offered are payment options (e.g. take-and-pay, weekly, monthly, by post, at a bank, or at a local office including flexible payment systems) and shared management options (private and community management).

(c) Sell options using suitable promotion techniques. This will require careful planning and implementation, particularly when dealing with groups who use alternative water supplies or if they have unauthorised pipe connections and do not currently pay.

(d) Services provided to a good quality standard that requires utilities to adopt a programme of continual organisational improvement, centred on existing and potential customers. In addition, effective collaboration between different departments within a utility (such as customer relations, billing, operation and maintenance, financial management) can enable the resolution of most customer complaints and enhance customer satisfaction.

\section{I. Current use of strategic marketing}

Most water utilities in developing countries have not yet adopted strategic marketing approaches. This is evident because they do not generally follow the principles of the customer value chain. For example, there is little emphasis on getting to know and understand consumers by obtaining information against key indicators on the various consumer groups in their city (including the poor). In addition, there is little evidence of effective initiatives by public water utilities to target different consumer groups with a variety of service options. Service options tend to be limited to house connections, water kiosks and commercial connections. It is important for a water utility to offer service and payment options that meet the requirements or demands of different consumer groups; for example, shared water connections may be affordable where individual house connections are not.

Some of the international private water companies are, however, to some extent using marketing approaches (for example, by offering more service and payment options). The key to understanding existing and potential customers is market segmentation.

\subsection{Market segmentation}

Segmentation is the process of identifying groups of customers with enough characteristics in common to make possible the design and presentation of a product or service each group needs. ${ }^{11}$ By identifying a segment's special needs, the service provider can then design services to meet them better and in a 
financially sustainable manner. A market may be segmented according to demographic dimensions such as income, house type, education level, family size and location. Each may have different relevance to a particular business.

The types of dwelling in which people live are generally a reflection of their socio-economic status. Those who live in slums and other informal settlements are generally the very poor (and often the more excluded from conventional services), while those in well-planned residential estates tend to be the more affluent in the population. The type of dwelling is therefore a convenient method by which a water utility could segment the water market.

In the Mombasa research, ${ }^{4}$ dwellings were categorised into four segments

(a) bungalows and maisonettes

(b) flats

(c) one-, two- or three-roomed dwellings (Swahili type of dwelling)

(d) dwellings located in unplanned informal settlements (slums) made of informal (unconventional) building materials such as reused timber, iron sheets, packaging boards and paper.

In many cities in developing countries, needs and conditions differ from one customer group or market segment to the next. People also experience substantially different water services specific to their market segment. For instance, Table 1 shows a summary of the water services experienced by the selected market segments in Mombasa. This information was obtained through a comprehensive survey of existing and potential customers, as part of the strategic marketing field research in 2000.

Market segmentation provides a basis for water utilities to structure service delivery and pricing policy to suit the special needs of each customer group. Suitable options for improved services need to be developed bearing in mind the different needs and demands of these groups. Though the product delivered to all segments in the water market would be similar (good-quality potable water that meets the necessary standards), the method of delivery, and hence the service would be different to suit the segment's special requirements and willingness to pay.

\section{IMPLEMENTING THE STRATEGIC MARKETING METHODOLOGY}

Three common principles of strategic marketing that can be followed by water utilities are as follows. ${ }^{6}$

(a) Where are we now?

(b) Where do we want to be?

(c) How might we get there?

\section{I. Where is the utility now?}

Utilities wishing to implement the strategic marketing approach need to obtain information about their existing and potential customers. This information can be obtained by carrying out a comprehensive customer (consumer) survey and willingness-topay study in all customer groups. Data on existing and potential customers are confirmed and a summary of existing water services obtained. An example of such a summary is shown in Table 1. Customers' preferences and willingness to pay for water service options priced at cost-covering levels are also obtained. In some consumer groups such as those living in the informal settlements, focus group discussions can be conducted to collect additional data, including their perceptions and preferences for priced water service options. An institutional analysis of the utility and its water supply infrastructure is carried out, including analysis of the utility's operating environment.

\subsection{Achieving utility objectives (where do water utilities need to be?)}

A progressive urban water utility or municipality typically has the objective to improve service provision to all groups of existing and potential customers, while meeting its financial objectives. Other objectives for utilities may include ${ }^{8}$

(a) to capture more of the water market

(b) to achieve equity in service provision by serving excluded groups (such as the poor, most of whom are currently not served and rely on alternative sources)

(c) to improve customer service

(d) to improve the utility's financial position.

An additional and strategic objective for a progressive water utility is to meet the social good in terms of providing water to those currently not served by the utility. It has often been stated that water supply is a key determinant in social inclusion, particularly taking into account the fact that those lacking access to safe water supply are clearly disadvantaged. A situation where a large segment of the society is excluded from water utility services is not politically sustainable. The strategic marketing approach provides the water utility with a logical methodology to identify, anticipate and satisfy the needs of those currently excluded from utility water services, and in a financially sustainable manner. The following steps can facilitate achievement of this strategic objective.

Using market segmentation, data are collected through a customer survey of existing and potential (unserved) customers in the entire area where the utility has mandate. The data collected (where is the utility now?) are used as the basis for making projections of necessary improvements in water supply infrastructure. Results of the customer survey, willingness-topay study and the population profile are used to estimate takeup of (technically feasible and manageable) service options. Projections of costs for improvements and the revenue that the utility can obtain from improvements in water services are then worked out. It is recommended that the average incremental cost (AIC) method of calculation be used to project costs of infrastructure improvements. ${ }^{4}$

Revenues are estimated with tariffs set taking into account the willingness to pay for each segment of customers. In setting tariffs, cross-subsidies may be made (for equity or social good purposes) between customer segments while maintaining the required average tariff. The costs of providing the required services are then compared with proposed revenues to check for financial sustainability. 


\begin{tabular}{|c|c|}
\hline Service options & Projections for option take-up in each market segment \\
\hline 12-24 h supply at individual house connection & $\begin{array}{l}\text { - Bungalows and maisonettes ( } 100 \%) \\
\text { - Flats }(80 \%) \\
\text { - One-, two- or three-roomed dwelling and Swahili houses (25\%) }\end{array}$ \\
\hline 12-24 h supply through shared connection & - Flats (20\%) \\
\hline 12-24 h supply at shared yard connection & $\begin{array}{l}\text { - One-, two- or three-roomed dwelling and Swahili houses (30\%) } \\
\text { - Dwellings in informal settlements (10\%) }\end{array}$ \\
\hline I2-24 h supply at shared yard connection with storage tank & $\begin{array}{l}\text { - One-, two- or three-roomed dwelling and Swahili houses (30\%) } \\
\text { - Dwellings in informal settlements (10\%) }\end{array}$ \\
\hline Privately managed kiosks with storage & $\begin{array}{l}\text { - One-, two- or three-roomed dwelling and Swahili houses (I0\%) } \\
\text { - Dwellings in informal settlements (40\%) }\end{array}$ \\
\hline Community managed kiosks with storage & $\begin{array}{l}\text { - One-, two- or three-roomed dwelling and Swahili houses (5\%) } \\
\text { - Dwellings in informal settlements (40\%) }\end{array}$ \\
\hline
\end{tabular}

\subsection{How might we get there?}

Implementation of the necessary improvements in water supply infrastructure to facilitate provision of the required services is then carried out. Proposals for institutional and management improvements necessary for provision of the required services at the prices indicated by respective segments of existing and potential customers are then developed and implemented.

Once the lists of service options and prices to be offered to each market segment have been agreed, a comprehensive promotion strategy and institutional improvement plan will be required to achieve adequate take-up of the options that can lead to financial sustainability. An example of projections for options take-up in each market segment in Mombasa is shown in Table 2 .

Research has shown that people living in inadequately served areas often pay high prices to vendors (\$1-5 per cubic metre in three cities in East Africa). This suggests a high willingness to pay for improved water services. The results of the customer survey and willingness-to-pay study for each service option and respective market segment in Mombasa revealed that customers and those excluded (potential customers) are willing to pay substantial amounts for improved water services. The study shows the potential for water utilities to achieve the above objectives using the strategic marketing approach.

\section{CONCLUSIONS AND RECOMMENDATIONS}

In this paper, the authors have attempted to provide the rationale for using a strategic marketing approach in the urban water sector, with a focus on developing countries. Strategic marketing offers a systematic and flexible approach to providing improved and sustainable services to all consumer groups or segments, including the often excluded poor.

The strategic marketing methodology adapted using research data from Mombasa demonstrates that by structuring service delivery options with appropriate pricing, utilities can improve water services to existing customers and serve more potential customers, at affordable costs and achieve financial sustainability. It is recommended that water utilities should consider using the strategic marketing approach as it has potential to improve services to existing and potential customers while meeting utility objectives such as improving the utility's revenue base. The strategic marketing approach has very good potential in improving services to the large number of those in developing countries who are currently excluded from conventional water services.

\section{ACKNOWLEDGEMENTS}

This paper is an output from a project funded by the UK Department for International Development (DFID) for the benefit of developing countries. The views expressed are not necessarily those of the DFID. The authors wish to thank the DFID for providing financial support for the research.

Cyrus Njiru bases this paper on his $\mathrm{PhD}$ research work at the Water, Engineering and Development Centre (WEDC), Loughborough University in the UK. The role of Mr Ian Smout as Research Supervisor and Dr Andrew Cotton as Director of Research is gratefully acknowledged. Thanks to other members of the PSDP research team at WEDC (Sue Coates), the Netherlands (Dr Richard Franceys), India (Srinivas Chary) and Uganda (Sam Kayaga) for their various roles and support during the research work. The views expressed in this paper are those of the authors and do not necessarily reflect the views of WEDC or the organisations that collaborated in the research.

The authors wish to thank the management and staff of National Water Conservation and Pipeline Corporation (NWCPC) who facilitated the study and the enumerators for their useful contribution in the fieldwork. Thanks also to the management and staff of Mombasa Municipal Council and the facilitators of focus group discussions in informal settlements. The residents of various segments in Mombasa provided information through questionnaires and focus group discussions without which the study would not have been successful.

\section{REFERENCES}

1. World Health ORganisation (WHO/UNICEF). Global Water Supply and Sanitation Assessment 2000 Report. Accessed on 20 October 2001 at http://www.who.int/water_sanitation_health/Global1.htm, dated 2000.

2. Colligon B. and Vezina M. Independent Water and Sanitation Providers in African Cities; Full Report of a Tencountry Study. UNDP-World Bank Water and Sanitation Program, World Bank, Washington, DC, April 2000.

3. NJIRU C. and SANSOM K. Optimising cost recovery through 
service differentiation and pricing: initial findings from Mombasa, Kenya. Proceedings of the 2nd Regional Conference on the Reform of the Water and Sanitation Sector in Africa, Kampala, Uganda, February 2001.

4. NJIRU C. Managing Urban Water Services through Segmentation, Service and Price Differentiation: Findings from Sub-Saharan Africa. Unpublished PhD thesis, Civil and Building Engineering Department, Loughborough University, March 2002.

5. Jones P. (ed.) Management in Service Industries. Pitman, London, 1989.

6. Wilson R. M. S. and GiLligan C. Strategic Marketing Management: Planning, Implementation and Control, 2nd edn. Butterworth-Heinemann, Oxford, 1997.

7. National Water Conservation and Pipeline CoRporation (NWCPC). Corporate Development Plan. Prepared for NWCPC by WS Atkins International Ltd in association with PriceWaterhouse, London, 1995.
8. NJiRU C and SANSOM K. Strategic Marketing Plan for Water Services in Mombasa and Coastal Region. WEDC, Loughborough University, February 2001.

9. SAGE R. Meaningful Relations, Water Services. London, 2000.

10. Sansom K., Coates S., Nuiru C. and Franceys R. Strategic Marketing to Improve both Water Utility Finances and Services to Poor Urban Water Consumers. A discussion paper produced by Water, Engineering and Development Centre (WEDC), Loughborough University, June 2000.

11. HeSKET J. L. Managing in the Service Economy. Harvard Business School Press, Boston, Massachusetts, 1986.

12. NJiRu C., Smout I. K. and SAnsom K. Managing water services through service differentiation and pricing in an African City. Journal of the Chartered Institution of Water and Environmental Management (CIWEM), 2001, 15, Nov., 277-281.

Please email, fax or post your discussion contributions to the secretary by I December 2003: email: kathleen.hollow@ice.org.uk; fax: +44 (0)20 7799 1325; or post to Kathleen Hollow, Journals Department, Institution of Civil Engineers, I-7 Great George Street, London SWIP 3AA. 